\title{
The Entry and Exit Dynamics of Self-Employment in Canada
}

\author{
by \\ Zhengxi Lin*, Garnett Picot** and Janice Yates
}

No. 134

11F0019MPE No. 134

ISSN: 1200-5223

ISBN: 0-660-17744-7

Price: $\$ 5.00$ per issue, $\$ 25.00$ annually

Business and Labour Market Analysis

24 -H, R.H. Coats Building, Ottawa, K1A 0T6

* Statistics Canada (613) 951-0830

**Statistics Canada (613) 951-8214

Facsimile Number: (613) 951-5403

E-mail:linzhen@statcan.ca

March 1999

An earlier version was presented at an international conference on self-employment co-sponsored by the Organization for Economic Cooperation and Development (OECD), the Canadian Employment Research Forum (CERF) and the Candian International Labour Network (CILN), September 1998, Burlington, Ontario, Canada. We thank our discussant, Stephen Jones, and the OECD-CERF-CILN conference participants for helpful comments and suggestions. We are solely responsible for any errors remaining in the paper.

This paper represents the views of the authors and does not necessarily reflect the opinions of Statistics Canada. 



\section{Table of Contents}

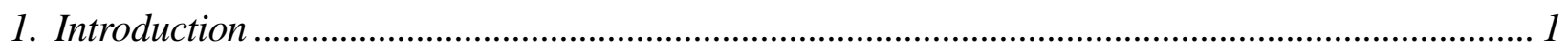

2. Self-Employment Entry and Exit Flows.............................................................................. 2

3. Patterns of Labour Market Status Transitions..................................................................... 5

3.1. Data and Definition ................................................................................................... 5

3.2. The Self-Employed vs Employees by Selected Characteristics .............................................. 5

3.3. Entry Into Self- vs Paid-Employment …………………………………………………...... 7

3.4. Exit Out of Self- vs Paid-Employment .............................................................................. 8

4. The Probability of Entering/Leaving Self-Employment............................................................. 9

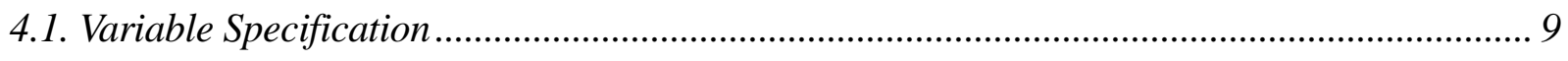

4.2. Empirical Results …………………………………............................................... 11

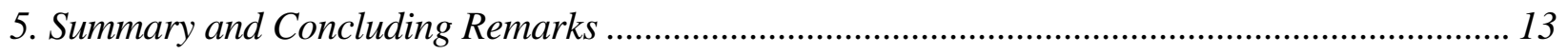

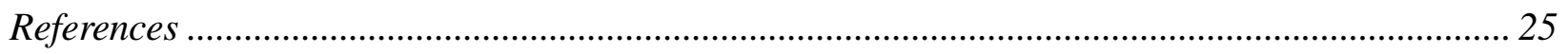





\section{Abstract}

This paper i) documents the extent and cyclicality of self-employment entry and exit flows; ii) explores transitions to and from self-employment; and iii) investigates the influence of individual characteristics and labour market experience as well as macroeconomic conditions on the probability of moving into or out of self-employment.

The self-employed sector now employs over two and a half million Canadian workers, has expanded on average by over $4 \%$ a year so far in this decade and accounted for over three out of every four new jobs the economy has created. There are substantial flows both into and out of selfemployment over the last 15 years. Gross flows into and out of self-employment averaged nearly half a million per year between 1982 and 1994, amounting to 42\% of the total self-employed population.

Regression results reveal no statistical evidence supporting the dominance of the push hypothesis over the pull hypothesis --- the notion that people are increasingly pushed into self-employment by deteriorating economic conditions. This analysis is done both through time-series analysis and the analysis of the determinants of flows into (and out of) self-employment. As in paid employment, younger Canadians are subject to higher turnover in self-employment --- they are not only more likely to enter but also substantially more likely to leave self-employment. Prior paid-employment experience and prior self-employment experience are both found to be associated with a higher likelihood of entering self-employment. The longer one is self-employed, the less likely he/she is going to leave the business. Having a spouse in business (being self-employed) substantially increases the likelihood of the other spouse becoming self-employed --- a self-employed spouse often attracts the other to either join the family business or start their own. We also find evidence that steady family income through paid-employment from one spouse increases the self-employed's (the other spouse's) affordability to continue with the business venture and hence reduces the likelihood of leaving self-employment.

Keywords: Self-employment, unemployment, not in the labour force, entry, exit JEL classification: J21; J24; J60 



\section{Introduction}

The objectives of this paper are to i) document the extent and cyclical variations of self-employment entry and exit; ii) explore transitions to and from self-employment; and iii) investigate the influence of individual characteristics and labour market experience as well as macroeconomic conditions on the probability of moving into or out of self-employment.

The motivation for this research arises from the increasing importance of self-employment, not only in Canada but also in many other countries. Nearly two and a half million Canadians reported working at their own businesses in 1997, more than double the number of self-employment twenty years ago. This unprecedented growth in Canadians' entrepreneurial endeavour in the 1990s, especially during a period of very slow paid growth in employment (a mere average $0.2 \%$ per annum), has been receiving increasing attention from the media, policy analysts, and academic researchers.

Given the numbers, this is not surprising. Self-employment accounted for $16.2 \%$ of the labour force in 1997 , up from $12.8 \%$ in 1989 , and $12.2 \%$ in 1979 . Presented in terms of job creation, the statistics command one's attention. In the first eight years of the 1990s, the labour market expanded by a total of 775 thousand jobs (5.9\%). Of this total net job growth, over three-quarters (nearly 600 thousand or $77.2 \%$ ) were created in the self-employed sector. This contribution to job creation from self-employment is unprecedented. During the previous decade, the economy created a total of over 2 million new jobs (a gain of 18.1\%) but expansion in self-employment contributed to less than one out of six new jobs created. The overwhelming majority $(82.7 \%)$ of net job creation was accounted for by growth in the paid-employment sector.

There are other striking differences in the growth trends of self-employment in the 1980s and 1990s. Notably, during the 1980s, nearly two-thirds of the self-employment growth was accounted for by business owners who also hired paid help. Suppose, very conservatively, a self-employed worker hired just one paid employee. The growth of self-employed employers in the 1980s would also have created the minimum of 228 thousand paid jobs. This has undoubtedly contributed to the strong growth of paid-employment during the expansion years of the 1980s.

This strong growth of self-employed employers was not evident in the 1990s. Only about $10 \%$ of the total increase in self-employment between 1996 and 1989 were employers with paid help. Ninetenths of this gain were entrepreneurs working on their own. This decreased tendency of the selfemployed to engage paid labour no doubt contributed to the slowdown in paid-employment growth in the 1990s.

While companion papers (Lin, Yates and Picot (1998); Picot, Manser and Lin (1998)) highlight more fully recent developments in self-employment in Canada and the United States and explores its cyclical fluctuations, this paper attempts to address the following questions. Are self-employed jobs stable in the sense that once self-employed, people tend to remain so for a relatively long period of time, implying low levels of turnover, especially exits? Or is self-employment simply a stopgap that people use until they find a paid job, implying significant entry and exit movements? Where, in terms of labour market status, do people come from when they enter self-employment or where are they going when they leave self-employment? What influence do individual 
characteristics and labour market experience as well as macroeconomic conditions have on the probability of moving into or out of self-employment? Answers to questions such as these are important if we are to understand the functioning of this increasingly important sector of the economy.

The analysis of entries and exits offers two advantages over that of levels. First, a given level at any particular point in time is determined by the stock of the previous period plus entries minus exits in the period. The entry and exit processes can be different, each with a different set of determinants. An examination of levels rather than entries and exits separately can mask the inherent differences between them. Second, even if a set of common factors influence both entries and exits, the extent of impacts can be different. Total effects observed from levels are the sum of that on each process, which can cancel each other out if working in different direction. Take the effect of unemployment on self-employment for example. Suppose no positive association is empirically found between the unemployment rate and the self-employment rate. Can this be interpreted as evidence rejecting the push theory? The answer is not altogether clear. It depends upon how unemployment affects both entries and exits. Unemployment can push a large number of people into self-employment and at the same time drive a large number of self-employed workers out of business. This would be clear evidence supporting the push hypothesis but the net effect on the total self-employment rate can be either statistically insignificant or empirically negligible. On the other hand, no association between the unemployment rate and the self-employment rate can be the results of unemployment having no impact on both entries and exits. This would be evidence that the push scenario does not dominate the pull hypothesis.

The rest of the paper proceeds as follows. Section 2 documents the extent of self-employment entry and exit flows and explores their cyclical variations using recently available longitudinal administrative data ( $\mathrm{T} 1$ files of Revenue Canada). Using longitudinal microdata extracted from the Survey of Labour and Income Dynamics (SLID) of Statistics Canada, Section 3 examines transitions to and from self-employment; and Section 4 investigates the influence of individual characteristics and labour market experience as well as macroeconomic conditions on the probability of moving into or out of self-employment. Finally, Section 5 closes the paper with a summary of major findings and some concluding remarks.

\section{Self-Employment Entry and Exit Flows}

Entries into and exits out of self-employment are calculated from longitudinal administrative data developed from the annual T1 files of Revenue Canada for 1981 to 1995 , based on $10 \%$ random samples. People are self-employed if they report earnings from self-employment in their personal income tax returns. Self-employment entries consist of income-tax filers who report earnings from self-employment in a year but not the previous; and self-employment exits occur when the incometax filer reports earnings from self-employment in one year but not the next. The self-employment rate is the number of the self-employed as a percentage of the total labour force (taken from the Labour Force Survey); the entry rate is the number of entries as a fraction of the total labour force; and the exit rate is the number of entries as a proportion of the self-employed population (taken from the $\mathrm{T} 1$ files). 
The self-employed are categorized into three groups: 1) those for whom self-employment earnings are the main source of earnings during the year; 2) those with self-employment earnings only --- the most restrictive; and 3) those with any self-employment earnings --- the least restrictive. Results presented here focus on the first measure, that is, for individuals for whom self-employment earnings are the dominant source of their earnings. ${ }^{1}$

There have been substantial flows both into and out of self-employment over the last 15 years (Table 1). On average, over a quarter of a million income-tax filers started their own business ventures every year between 1982 and 1995, amounting to over 22\% of the self-employed population. On the other hand, over two hundred thousand self-employed workers $(19.7 \%)$ ended their entrepreneurial pursuit every year between 1981 and 1994. Gross flows into and out of selfemployment averaged nearly half a million per year between 1982 and 1994, amounting to $42 \%$ of the total self-employed population. During the same period, entries outnumbered exits every year and the self-employment sector gained an average of nearly thirty thousand new workers per year $(2.5 \%)$.

Cyclical fluctuations of self-employment entry and exit flows can be assessed either from the raw data or through regression analysis. Figure 1 charts the self-employment rate, the entry rate and the exit rate against two labour market cycle indicators: the unemployment rate (Urate) and the fulltime paid-employment (FTPE) rate. A visual examination of the raw data reveals very little cyclical fluctuations of self-employment entries between 1982 and 1995. Exits showed a little more countercyclical variations between 1981 and 1994.

To further summarize the relationship between self-employment flows and labour market cycles, we turn to regression analysis by estimating the following pooled cross-section time-series fixed effects model:

$$
\mathrm{SE}_{\mathrm{it}}=\alpha_{0}+\alpha_{1} \mathrm{CYCLE}_{\mathrm{it}}+\alpha_{2} \text { PARTRATE }_{\mathrm{it}}+\alpha_{3}{ }^{\prime} \text { PROVINCE }_{\mathrm{i}}+\alpha_{4} \mathrm{TIME}+v_{\mathrm{it}},
$$

where the dependent variable $\mathrm{SE}_{\mathrm{it}}$ is the annual provincial self-employment rate or entry rate or exit rate; the explanatory variables are the labour market cycle indicator $\left(\mathrm{CYCLE}_{\mathrm{it}}\right)$, either the annual provincial unemployment rate or the annual provincial full-time paid-employment rate, ${ }^{2}$ the annual provincial labour force participation rate $\left(\mathrm{PARTRATE}_{\mathrm{it}}\right){ }^{3} \mathrm{PROVINCE}_{\mathrm{i}}$ denoting the 10 provinces,

1 All three measures produce very similar qualitative results, which are available upon request.

2 The unemployment rate is commonly used in the literature as the labour market cycle indicator. But, does the observed relationship hold when alternative indicators are used? To test the robustness of estimates across various indicators, we also use the full-time paid-employment rate and similar results are obtained.

3 Although the unemployment rate (full-time paid-employment rate) and the labour force participation rate both fluctuate cyclically and are negatively (positively) correlated, they are different cyclical indicators and each has different impacts on self-employment. To more precisely examine the impacts of the unemployment rate, we want to control for the impacts of labour force participation. However, dropping it from the regression does not empirically make much difference --- the magnitude of the coefficient on the unemployment rate (full-time paid-employment rate) only changes very slightly. 
TIME indicating time trend (i.e., TIME $=1$ for 1981,2 for $1982, \ldots \ldots, 15$ for 1995$){ }^{4}$ and $\mu_{\mathrm{it}}$ is the error term, assumed to be either cross-sectionally heteroskedastic but independent and time-wise autoregressive (usually referred to as partial pooling) or cross-sectionally correlated and time-wise autoregressive (usually referred to as full pooling). ${ }^{5}$

The model is estimated for men and women combined as well as separately. Table 2 reports sample statistics and the Generalized Least Squares (GLS) regression results on Equation (1) for the unemployment/full-time paid-employment rate. The men and women combined results on the selfemployment rate as well as the entry rate show that there is a statistically significant but empirically small negative (positive) relationship between self-employment and unemployment (full-time paidemployment). A $1 \%$ rise in the unemployment rate is found to be associated with $0.044 \%$ decline in the overall rate of self-employment with standard error of 0.009 and $0.178 \%$ decline in the entry rate into self-employment with standard error of 0.03 . And a $1 \%$ rise in the full-time paidemployment rate is found to be associated with $0.34 \%$ increase in the overall rate of selfemployment with standard error of 0.07 and $1.14 \%$ increase in the entry rate into self-employment with standard error of 0.2 .

The separate results for men and women largely confirm the above findings, the only differences being the magnitudes of estimates. Women's self-employment entry rate is substantially more negatively (positively) responsive to the unemployment (full-time paid-employment) rate than men's. The entry rate elasticity with respect to the unemployment rate is -0.289 with standard error of 0.038 for women compared to -0.06 with standard error of 0.024 for men; and the entry rate elasticity with respect to the full-time paid-employment rate is 1.808 with standard error of 0.112 for women compared to 0.455 with standard error of 0.189 for men.

The data also reveal a statistically significant but empirically small negative (positive) relationship between self-employment exits and unemployment (full-time paid-employment). A $1 \%$ rise in the unemployment rate is found to be associated with $0.14 \%$ decrease in the overall exit rate with standard error of 0.011 . There is little gender differential. And a $1 \%$ rise in the full-time paidemployment rate is found to be associated with $0.985 \%$ increase in the overall exit rate with standard error of 0.09 . Men's self-employment exits are significantly more positively responsive to full-time paid-employment than women's --- the exit rate elasticity with respect to the full-time paid-employment rate is 1.152 with standard error of 0.113 for men compared to 0.69 with standard error of 0.132 for women.

To summarize, annual flows into and out of self-employment are very large, involving over $40 \%$ of the self-employed in any given year. These large gross flows overwhelm the relatively small net flow (increase) of $2 \%$ to $3 \%$ since 1981. It must then be remembered that these flows are associated with jobs that provide the majority of the annual earnings to the worker. These are not secondary jobs taken to enhance substantial earnings from paid-employment. Furthermore, these large flows do not demonstrate a strong cyclical pattern, particularly entries. They have been rising steadily

4 The results were replicated without the time trend in the equation, and the association between the cycle indicator and self-employment was not affected.

5 See Kmenta (1971:508-514) for more details on the error term structure; and White (1993:245-54) for more details on the estimation techniques. 
since 1981, during recessions and expansions. Exits demonstrate a weak counter-cyclical behaviour as the self-employed appear somewhat more reluctant to exit in bad economic times.

\section{Patterns of Labour Market Status Transitions}

This section explores transitions to and from self-employment, while the next section investigates the determinants of moving into and out of self-employment. Since both these sections use the same data source, it is appropriate to begin with a brief discussion of the data and definitions.

\subsection{Data and Definition}

The data used in this section and the next are extracted from the longitudinal file of the Survey of Labour and Income Dynamics (SLID) of Statistics Canada for the years 1993 and 1994. SLID contains a wealth of information on individuals' labour market activities and experience, their incomes, and their personal as well as family characteristics. SLID offers numerous advantages for socio-economic research over other data sources. For the present study, its main advantages lie in its longitudinal nature, and its wealth of information. ${ }^{6}$

Based jointly on the labour force status and class of worker, an individual's weekly labour force status is determined by four mutually exclusive categories: not in the labour force, unemployed, paid worker or self-employed. An individual is considered to be newly self-employed in a year if he/she began a self-employed job in that year. Similarly, an employee who starts work with a new employer is said to start a new paid-job during the year.

Thanks to the availability of information on the number of hours worked in each job, we are able to determine, on a monthly basis, whether a worker started the job as his/her primary (including only) or secondary labour market activity. Arguments can be made for the use of either all starts or only main-activity starts in the analysis. We report results for both types of job starts where warranted.

\subsection{The Self-Employed vs Employees by Selected Characteristics}

After excluding unpaid family workers and those whose weekly labour force status cannot be determined (missing value), our original empirical sample for the analysis of entry into selfemployment in 1994 consists of 27,519 individual observations. Two further sample exclusions are applied. First, to focus the discussion on individuals of typical working age, we exclude 4,752 individuals 65 years of age and older in 1994. Second, more than a quarter of all jobs started in 1994 are found to be summer jobs held by students who returned to full-time education in the fall. Therefore, another 3,146 individuals who are defined as full-time students in both the beginning and ending months of 1994 are further excluded. Thus, our final empirical sample consists of 19,654 individual observations, representing nearly sixteen million working-age (15-64) Canadians in 1994.

6 Starting a new business in any given year is not a particularly high probability event among the population. Without a sufficiently large sample, there may not be enough cases for analysis. Although we would prefer an even bigger sample, we are satisfied that SLID's sample is reasonably big for this study. 
The following are a few descriptive highlights of the key features of self-employment and paidemployment. This sample includes all self-employed and paid workers, whether these were their major job or not. Many of these facts are by now well known (see Gauthier and Roy (1997), Statistics Canada (1997), Lin, Yates and Picot (1998)).

- Self-employment is more likely to be a male labour market activity. Men made up only $52 \%$ of employees but over two thirds of self-employed workers in 1994 (Table 3). Men's dominance of self-employment is even stronger when more restrictive definitions are applied. Among those who were self-employed only, seven out of ten were men.

- The age structure of the self-employed tends to be older than that of employees. Less than a quarter of the self-employed were under the age of 35 , compared to over $40 \%$ of employees. In contrast, those aged $45+$ accounted for nearly $42 \%$ of the self-employed but under $30 \%$ of employees.

- Education attainment among the self-employed is widely distributed and somewhat polarized. Those with less than high school education made up $21 \%$ of the self-employed, compared to under $18 \%$ among paid employees. On the other hand, $18.2 \%$ of the self-employed had at least a university degree, compared to $16.6 \%$ among employees.

- Self-employment is concentrated among some industrial sectors while nearly non-existent in others. Primary, construction, trade, business services and other services employed nearly $70 \%$ of the self-employed but only a little over one third of employees. In contrast, government and education services accounted for $17.1 \%$ of employees but merely $2.4 \%$ of the self-employed.

- On average, the self-employed reported earning about 92 cents for every dollar wage and salary workers made in 1994 (Table 4). But their earnings are more polarized --- a higher proportion of the self-employed at both the low and high end of the earnings distribution and a lower proportion in the middle. The median self-employment earnings were only two-thirds of that of employees. At the low end of the distribution ladder, over $56 \%$ of the self-employed earned under \$20,000; compared to 36\% among employees. In the middle, $38 \%$ of the self-employed earned between $\$ 20,000$ and $\$ 80,000$; compared to $62 \%$ among wage and salary workers. At the high end, $5.4 \%$ of the self-employed earned over $\$ 80,000$; compared to only $2.0 \%$ among employees. ${ }^{7}$ Very similar patterns of average earnings and polarization are observed when men and women are considered separately.

- The self-employment sector exhibits a similar male/female earnings gap as paid-employment does. The average self-employed woman earned 66 cents for every dollar made by her male counterpart. In comparison, women employees on average made 63 cents for every dollar their male counterparts earned.

7 Nearly $12 \%$ of the self-employed reported various degrees of financial losses as business revenues did not fully cover operational costs. They are not included in the calculations here. 
- Although the self-employed as a whole earned very close to what employees made, they put substantially more hours into work. The average self-employed logged nearly 2,290 hours into their businesses in 1994, nearly $30 \%$ more than the average of 1,770 hours employees worked. In particular, over $43 \%$ of self-employed workers put in over 2,500 hours compared with $7 \%$ among employees.

The pattern is very similar when working hours of self-employed men are compared to that of their employee counterparts --- self-employed men averaged $28 \%$ more hours; $51 \%$ of them put in over 2,500 hours compared with $11 \%$ among their employee counterparts. Self-employed women also worked more hours. They on average put in $15 \%$ more hours into work than their average employee counterpart; one in four of them logged more than 2,500 hours compared with one in thirty-seven among women employees.

\subsection{Entry Into Self- vs Paid-Employment}

In 1994, over a quarter of a million Canadians became newly self-employed, amounting to $14 \%$ of all self-employment in that year. ${ }^{8}$ Two-thirds of the newly self-employed started the business pursuit as their main labour market activity. ${ }^{9}$ While some of them left their paid jobs to become their own bosses, others started the endeavour from unemployment or not actively engaged in the labour force. Since our focus here is on the origin or destination of the self-employed, the labour market status of new entrants (both self-employed and employees) for one week, one month, three months, six months as well as one year prior to the entry is analyzed.

We consider the week immediately proceeding the entry first. As shown in Table 5, almost equal proportions of those entering any self-employment came from the three labour market status: paidemployment, unemployment and labour force inactive $\left(38 \%, 30 \%\right.$ and $32 \%$, respectively). ${ }^{10}$ The self-employed are much less likely to enter the job from unemployment than are new paid workers, and more likely to come from out of the labour force. Fifty-seven percent of those starting paid employment came from unemployment; a significantly lower proportion (8\%) from not in the

8 The entry rate observed from our SLID sample is somewhat lower than that based on the T1 taxation data sample reported earlier. This is likely due to definitional differences between the two data sources --- hours of work are used to defined the "main" or "primary" activity in SLID but earnings are used in the T1. It can also arise from sample exclusions --- full-time students are excluded in SLID but included in the T1; those aged 65+ are excluded in SLID but included in the T1. And the length of reference time period is different --- activity is defined in a month in SLID but the entire year in the T1.

9 For entrants, self-employment is defined as the main labour market activity if hours of work in self-employment exceed that of paid work in either the month of entry or after entry. For the rest of the population (other than entrants), self-employment is defined as the main labour market activity if hours of work in self-employment exceed that of paid work in any month of the year.

10 We are working at the person level --- only one entry is allowed for any given individual. For those who made more than one entry, only the first is counted. Furthermore, for those self-employed who provided services under contract, SLID defines new contract starts as new job starts but does not distinguish a contract renewal from the same client from a new contract offer by a new client. Therefore, individuals who reported ending a self-employed job in one week and starting another right in the following week are not classified as new starters. On the other hand, those who experienced at least one week break between finishing one self-employed job and commencing another are defined as new starters. 
labour force; another one-third either left their previous paid- or self-employed job. Very similar patterns of labour market transitions are observed when entry into self-employment as the main labour market activity is compared to entry into paid-employment as the main labour market activity.

Moving further and further back from the week when the entry occurred, the proportion of selfemployment entrants as well as paid-job starters originated from employment gradually increases whereas the proportion originated from unemployment and labour market inactive steadily declines. One full year before starting the new job, nearly half of those entering self-employment were employees; $16 \%$ were self-employed; $12 \%$ were unemployed, and $20 \%$ were not in the labour force. The self-employed were less likely to be unemployed prior to entry than were paid employees, no matter what the time period used.

To summarize, these data suggest that the motivation to enter self-employment is somewhat different from that of entering paid jobs. In particular, new entrepreneurs are much less likely to be escaping unemployment than are new paid workers, but they are much more likely to have been outside the labour force prior to entry. There are slight differences between men and women. While new female entrepreneurs are marginally less likely to be escaping unemployment than their male counterparts, they are more likely to originate from outside the labour force.

\subsection{Exit Out of Self- vs Paid-Employment}

Our final empirical sample for the analysis of exit out of self-employment in 1993 consists of 13,403 individual observations, representing nearly 10 million Canadian workers between the ages of 15 to 64 who were not full-time students.

In 1993, nearly 300,000 business owners ceased to be self-employed, representing $16.7 \%$ of all persons self-employed in 1993. ${ }^{11}$ For over three-quarters of them, working on the business was their main labour market activity. ${ }^{12}$ While some left to work for others, others became unemployed or dropped out of the labour force.

The labour market status for exiters (both self-employed and employees) is reported in Table 6, for one week, one month, three months, six months as well as one year after they left their old jobs. In the week immediately after leaving the old job, $36 \%$ of self-employment exiters were working for others; $24 \%$ were unemployed; and $41 \%$ dropped out of the labour force ${ }^{13}$ In comparison, a lower proportion of paid-employment exiters (30\%) were working for another employer; 3\% were

11 The exit rate observed in SLID is also lower than that from the T1 files, see Footnote 9 for likely causes.

12 For exiters, self-employment is defined as the main labour market activity if hours of work in self-employment exceed that of paid work in either the month of exit or before exit. For the rest of the population (other than exiters), self-employment is defined as the main labour market activity if hours of work in self-employment exceed that of paid work in any month of the year.

13 As with entries, only one exit is allowed for any given worker. For those who made more than one exit, only the first is counted. Furthermore, individuals who reported ending a self-employed job in one week and starting another right in the following week are not classified as exiters. On the other hand, those who experienced at least one week break between finishing one self-employed job and commencing another are defined as exiters. 
working on their own; a higher fraction (37\%) were unemployed; and a lower proportion (30\%) were not in the labour force. Very similar patterns of labour market transitions are observed when exit out of self-employment as the main labour market activity is compared to exit out of paidemployment as the main labour market activity.

Moving further and further ahead after the exit occurred, the proportion of self-employment as well as paid-job exiters working for others or on their own steadily increases; whereas the proportion being unemployed or labour market inactive steadily declines. One full year after leaving the old job, $40 \%$ of self-employment exiters were working for others; $18 \%$ were working on their own again; $12 \%$ were unemployed; and $27 \%$ were not in the labour force. In comparison, a much higher proportion $(57 \%)$ of those ending paid-employment were working for a different employer; a substantially smaller fraction $(6.1 \%)$ were working for their own significantly lower fraction (18\%) were not in the labour force.

Do the self-employed leave their job primarily to enter paid-employment when the opportunity rises. Some do, but not the majority. From one-quarter to $40 \%$ are in a paid job within the first few months. About one-quarter find themselves unemployed, but many leave the labour force. This tendency to exit the labour force is what primarily distinguishes the self-employed from the paid worker exits. And apparently there is a strong tendency to become self-employed again either for positive or negative reasons.

\section{The Probability of Entering/Leaving Self-Employment}

Are people pushed into or forced out of self-employment by unfavourable macroeconomic conditions? What influence does individuals' labour market experience have on the decision to enter or leave self-employment? What are the individual and family characteristics associated with a relatively higher probability of moving into or out of self-employment? This section addresses these questions by estimating the probability of entering and leaving self-employment.

\subsection{Variable Specification}

For the entry equation, the dependent variable is defined to take the value of one if the individual started self-employment in the year; and zero otherwise. And for the exit equation, the dependent variable is defined to take the value of one if the worker ceased to be self-employed in the year; and zero otherwise.

Economic theories on the determinants of self-employment can be generally categorized into two contrasting schools, according to their respective central assumption on the role of unemployment. The so-called "recession push" school of theories assumes that self-employment is largely opportunistic and argues that self-employed workers are not endowed with special abilities that differentiate them from paid-workers but instead are merely responding to the environmental circumstances in which they find themselves in a particular place or at a particular time. It would easily follow from this view that self-employment is positively associated with unemployment as it is argued that people who would otherwise prefer to work in paid-employment are "pushed" into establishing their own business ventures because they cannot find suitable paid-employment opportunities. 
Opposite to the "push" hypothesis is the commonly known "entrepreneurial pull" school of theories, which assumes entrepreneurs as individuals with particular abilities and argues that self-knowledge of these particular abilities motivates them to engage in risk-taking entrepreneurial pursuit. Since self-employment is the simplest form of entrepreneurship, it would naturally follow from this hypothesis that there is no positive relationship between self-employment and unemployment. A negative relationship is possible as it is often argued that high unemployment reduces the incentives to enter self-employment for two reasons. First, when macroeconomic conditions are unfavourable and unemployment is high, people are less likely to enter self-employment knowing that the business has a higher probability of failure. Second, during periods of high unemployment, offers of paid employment opportunities are less frequent and individuals are less likely to enter selfemployment knowing that the probability of finding other employment is low if the venture fails.

Empirical evidence supporting both hypotheses is available, at the individual as well as aggregate level. Due to space limitation, we do not provide a lengthy literature review here, as is done in a companion paper (Lin, Yates and Picot (1998)). Instead we focus on the specification of the explanatory variables that are expected from basic economic principles to influence the decision to enter/leave self-employment.

Within the framework of our data, the vector of $\mathrm{X}$ can be classified into four categories: macroeconomic conditions; human capital variables; family-related characteristics; and other demographic controls. As mentioned earlier, some argue that lack of paid-employment opportunities under high unemployment may push people into self-employment. Others see high unemployment as an obstacle for entering self-employment as the venture faces a higher probability of failure under unfavourable economic conditions. From the exit side, we can also argue that high unemployment may push business owners to leave because the business has failed or force self-employed workers to stay due to a lower probability of finding other employment. The provincial unemployment rate enters our model to empirically investigate the influence of macroeconomic conditions on selfemployment entry/exit.

Self-employed workers differ from paid-employees in that they require financial resources to start and skills to run the business. While a direct measure of financial assets is absent from our data, human capital can be approximated by age, education attainment and prior self-employment experience. In addition, it is believed that some self-employed workers derive a significant proportion of their work from firms with which they were previously engaged as paid employees. It is hence reasonable to expect that prior paid-employment experience positively influences the decision to enter self-employment as it builds up social contacts with previous employers as well as colleagues and others. For the exit equation, it is reasonable to expect that the longer one has been self-employed, the less likely he/she is to leave.

Self-employed workers also differ from employees in that they bear more financial uncertainty and operational risks. If their spouses are already self-employed, entry and operating costs would be greatly reduced. On the other hand, if their spouses are paid-employees, especially full-time and full-year, financial uncertainty associated with being in business diminishes as steady pay cheques flow into the household. One is less reliant on business income to support the family. Furthermore, most full-time full-year paid jobs in Canada provide a host of benefits for all family member such as medical insurance and dental care plans. Therefore, the presence of a self-employed spouse as well 
as full-time full-year paid-employed spouse is expected to positively influence entry into selfemployment and negatively influence exit out of self-employment.

Other demographic controls include gender, marital status, visible minority status, disability status, immigrant status, first language and presence of dependent children, variables which have been shown in other work to influence not only the choice between self-employment and paidemployment but also the decision whether or not to work at all.

\subsection{Empirical Results}

As discussed in the previous section, our final empirical sample for the analysis of entry into selfemployment in 1994 consists of 17,919 unweighted individual observations between the ages of 15 to 64 who were not full-time students. There are two empirical samples for the analysis of exit out of self-employment in 1993: 2,096 unweighted individual observations for exit out of any selfemployment activity; and 1,842 unweighted individual observations for self-employment as the main labour market activity. Again, full-time students and those aged 65+ are excluded. Sample statistics are reported in the appendix. ${ }^{14}$

Table 7 reports logistic regression results and estimated probabilities of entering self-employment in 1994 or leaving self-employment in $1993 .^{15}$ The results are reported for any self-employment activity as well as for self-employment as the main labour market activity. These are for men and women combined. The main points based on the results for "any" self-employment are summarized as follows:

- The unemployment rate coefficient is positive in both the entry and exit regressions but statistically insignificant by conventional standards. Regarding entry, there is thus no statistical evidence that the "push" theory (associated with poor economic conditions) dominates the "pull" theory. Both may be at work, but this analysis does not support one over the other. This is consistent with the time-series regression results reported earlier. Regarding the exit, the results also do not support the notion that the self-employed leave the business primarily because they are pushed out in poor economic times. ${ }^{16}$

14 All results reported here are adjusted by using sampling weights.

15 Entry as well as exit is a relatively low-probability event. Hence, both probit and logit models are estimated and they show very similar qualitative results. The logit regression results are reported here and used to compute probabilities. The logit regression model is $\operatorname{Ln}[\mathrm{P} /(1-\mathrm{P})]=\beta \mathrm{X}$, it follows that $\mathrm{P}=\exp (\beta \mathrm{X}) /[1+\exp (\beta \mathrm{X})]$. Regressions are also run for men and women separately. The results are generally similar and hence are not reported here. Furthermore, the unweighted sample of female self-employed workers used in the exit analysis is relatively small. Earlier specifications also include as regressors the provincial unemployment rate lagged for one year, dummy variables on marital status, visible minority status, disability status, immigrant status, first language, the presence of dependent children aged 5-12; and industry for the exit equations. They are all statistically insignificant and therefore dropped in the final regressions.

16 We also attempted to explore the relationship between individual duration of unemployment and the probability of self-employment entry through competing-risk hazard analysis by focusing on the newly unemployed. Unfortunately the number of those who subsequently became self-employed is too small to render any conclusive evidence. 
- Almost all age dummy variables are negative and significant, implying younger Canadians (1534) are more likely to enter self-employment. At first glance, this seems at odds with previous findings that older people are more likely to be self-employed. However, an inspection of the exit results reveals that younger people are also substantially more likely to leave selfemployment. Thus, the entry and exit results together suggest that younger people are subject to higher turnover in the labour market, no matter whether self-employed or in an a paid job. ${ }^{17}$

- All the education dummy variables are not statistically significant, suggesting little difference in the probability of entering self-employment among different education groups (except elementary, where the probability is lower). However, the probability of exiting is lower (and marginally significant) among the more highly educated, suggesting longer tenure of selfemployment among the more highly educated.

- Experience plays an important role in influencing the decision to enter or leave selfemployment. Persons with paid-employment experience are $35 \%$ more likely to start a business than those without such experience. Furthermore, those previously self-employed are nearly twice as likely to become self-employed as those who were not.

- As expected, the longer one is self-employed, the less likely he/she is going to leave the business. Other things being equal, those in business for 11 years (an increase of a year from the mean) have their probability of leaving the business reduced by $10 \%$ from that of those being self-employed for 10 years (the mean); and those being in business for 19 years (an increase of one standard deviation from the mean) are only one-third as likely as the average to end the business pursuit.

- Those whose spouses are self-employed are four times as likely to enter self-employment as others. This supports the notion that when one spouse is established in self-employment, the other is often also attracted into the family business. And self-employed workers with full-time full-year paid-employed spouses are only half as likely to leave self-employment as other, supporting the hypothesis that full-time full-year paid-employment in the family increases selfemployed workers' affordability to continue on the business venture by reducing the household's financial reliance on the business income.

- Women are not only less likely than men to start a business, they are also more likely to leave self-employment. The presence of dependent children aged 0-4 is associated with a higher probability of both entering and leaving self-employment.

17 Evidence on more frequent job separations, hirings and hence higher overall turnovers in the paid-employment sector among young people is documented in Picot and Lin (1997). 


\section{Summary and Concluding Remarks}

Growth of self-employment is nothing new in Canada. It has been on the steady rise since the early 1970s. What is remarkable, however, is its fast pace of expansion in the 1990s. This sector now employs over two and a half million workers, has expanded on average by over $4 \%$ a year so far in this decade and accounted for over three out of every four new jobs the economy has created. Many have attempted to explain the causes of this striking upward trend by documenting the evidence, empirical modelling as well as international comparison.

Macroeconomic conditions are a potential cause frequently considered, discussed and debated. Many argue that high unemployment and the lack of paid employment opportunities in the 1990s pushed people into self-employment at an increasing rate. Others dispute this argument by noting that although the unemployment rate in the 1990s remains persistently high, it is nevertheless no higher than what Canada experienced in the 1980s when self-employment trends were very different.

A series of other non-cyclical factors may be behind the unprecedented rising level and rate of selfemployment in the 1990s. In broad terms, these include demographic shifts (e.g., ageing and increasing education attainment of the population, declining labour force participation of youth and women in recent years, increasing level of immigration) resulting in a relatively larger pool of the labour force who have a higher propensity to be self-employed; government and corporate restructuring and down-sizing leading to an increased supply of experienced and skilled workers relatively better equipped with managerial skills and social networks to start and operate a business; technological advances leading to lower operating costs and more opportunities for small businesses, especially home-based ones; structural change that results in shifts towards industries and occupations in which self-employment is traditionally more prominent; more contracting-out by employers largely in response to trade globalization and increasing international competition as well as higher indirect labour costs such as payroll taxes; public policies such as rapid growth of personal income taxes (which encourage self-employment where earnings can be sheltered) and payroll taxes (which discourage paid-job creation), provision of assistance to the unemployed for starting business ventures, lower interest rates and easier access to financing for small businesses; popular perception of increasing uncertainty and instability in the wage and salary sector mainly arising from restructuring and down-sizing by governments and particularly big corporations; increasing entrepreneurial spirit as well as preference for being one's own boss. ${ }^{18}$

The debate about these numerous possibilities continues. This paper has attempted to advance our knowledge and understanding of self-employment by examining the entry and exit processes. The data on hand demonstrates substantial flows both into and out of the self-employment sector over the last 15 years, although the magnitude of the flows differs between the two data sources used (for the years in which information is available in both). According to the taxation data, gross flows into and out of self-employment averaged nearly half a million per year between 1982 and 1994, amounting to $42 \%$ of the total self-employed population. Entries outnumbered exits every year and

18 For a more detailed review and discussion of the effects of unemployment and other non-cyclical factors on the rising trend of self-employment, see Lin, Yates and Picot (1998) and the references therein. 
the self-employment sector gained an average of nearly thirty thousand new workers per year $(2.5 \%)$ during the same period.

Time-series regression analysis shows a statistically significant and empirically small negative relationship between self-employment entries and unemployment. We also find a statistically significant and empirically small negative association between self-employment exits and unemployment. In related work (Picot, Manser and Lin (1998)), we also find a statistically significant and empirically small negative correlation between the self-employment rate and unemployment rate. Hence, there does not appear to be any evidence that the "push" process dominates the "pull", at least over the business cycle. Both may be at work, but when unemployment rises and full-time paid jobs decline, we find no evidence of either an increase in the flows into self-employment or a rise in the self-employment rate. As noted earlier, unemployment in the 1990s has been at about the same level as during the 1980s, but the rapid growth of selfemployment was not observed during that decade.

The short-run (one week) labour market status transitions among job starters reveal that relative to paid-job starters, a higher fraction of self-employment entrants originated from wage and salary employment; a much lower fraction from unemployment; and a significantly higher proportion from out of the labour force. Hence, the new entrepreneurs are not predominantly people escaping unemployment.

The short-run labour market status transitions among job leavers demonstrate that relative to those leaving a paid-job, a higher fraction of those leaving self-employment left to work for others; a much lower fraction became unemployed; and a significantly higher proportion dropped out of the labour force. For whatever reasons, there appears to be strong flows from and to "out of the labour force". This is true for both men and women.

As noted earlier, regression results on the determinants of the decision to enter/leave selfemployment reveal no statistical evidence supporting the argument that deteriorating macroeconomic conditions result in an increase in the number of people being pushed into selfemployment or driven out of business. As in the case of wage and salary employment, younger Canadians (15-34) are subject to higher turnover in the self-employment sector. They are not only more likely to enter self-employment but also substantially more likely to exit. While education level does not seem to significantly affect the decision to enter or leave self-employment, prior paidemployment as well as self-employment experience is associated with a higher likelihood of entering self-employment. The longer one is self-employed, the less likely he/she is going to leave the business. The presence of a self-employed spouse is associated with a higher probability of entering self-employment, supporting the notion that once a spouse is established as a selfemployed entrepreneur, this has a significantly positive effect on the partner joining the business or starting their own. The presence of a full-time full-year paid-employed spouse is found to reduce self-employed workers' likelihood of leave the business, supporting the hypothesis that steady family income through paid-employment increases self-employed workers' ability to continue on the business venture by reducing the household's financial reliance on the business income.

With the above summary of our main findings, we conclude by noting a set of constraints that this work has faced but can be addressed in future research. First, we attempted to explore the 
relationship between individual duration of unemployment and self-employment entry through competing-risk hazard analysis. Unfortunately, the number of the newly unemployed who subsequently became self-employed in our data is too small to render any conclusive evidence. As more years of SLID data become available, we shall be able to more conclusively assess the effects of unemployment duration on entry into self-employment.

Secondly, it is commonly theoretically argued and empirically documented that financial resources play an important role in determining whether individuals are self-employed or decide to start up a business as they often face finance and liquidity constraints (e.g., Blanchflower and Oswald (1998) and references therein, Fairlie (1997)). Although our measure of presence of a full-time full-year paid-employed spouse reflects to a certain degree the family financial situation, our analysis lacks any direct measure of family asset/wealth. Another capital-related issue is monetary policy. In addition to one's own resources, people can also borrow to finance a business. Although the extent of leverage financing often depends upon asset availability (for collateral or mortgage purposes), interest rates are another key determinant in people's borrowing decisions and thus expected to influence self-employment entry/exit. We hope to address this in future work.

Thirdly, as discussed above, taxation policies have frequently been argued to impact selfemployment but we are not able to cover them in this analysis. Finally, limited by data availability, our analysis is confined to a single year at a particular phase of the business cycle. Even though variations in the unemployment rate across provinces is found to have little impact on entries into and exits out of self-employment, patterns of labour force status transitions, as well as selfemployment entry and exit processes can be different at a different phase of the business cycle. We await further data to address this in future analysis.

\section{Table 1: Self-Employment Entry and Exit Flows, Canada, 1981-1995}

\begin{tabular}{lccccccccc}
\hline & Level & \multicolumn{2}{c}{ Entry } & \multicolumn{2}{c}{ Exit } & \multicolumn{2}{c}{ Gross Flow } & \multicolumn{2}{c}{ Net Flow } \\
& & Number & \% of Level & Number & \% of Level & Number & $\%$ of Level & Number & $\%$ of Level \\
& \multicolumn{1}{c}{$(1)$} & $(2)$ & $(3)=(2) /(1)$ & $(4)$ & $(5)=(4) /(1)$ & $(6)=(2)+(4)$ & $(7)=(6) /(1)$ & $(8)=(2)-(4)$ & $(9)=(8) /(1)$ \\
\hline 1981 & 915,140 & n.a. & n.a. & 178,620 & 19.5 & n.a. & n.a. & n.a. & n.a. \\
1982 & 931,240 & 194,750 & 20.9 & 175,470 & 18.8 & 370,220 & 39.8 & 19,280 & 2.1 \\
1983 & 953,350 & 197,700 & 20.7 & 172,810 & 18.1 & 370,510 & 38.9 & 24,890 & 2.6 \\
1984 & 988,590 & 208,030 & 21.0 & 194,820 & 19.7 & 402,850 & 40.7 & 13,210 & 1.3 \\
1985 & 990,980 & 197,280 & 19.9 & 193,490 & 19.5 & 390,770 & 39.4 & 3,790 & 0.4 \\
1986 & $1,019,390$ & 221,760 & 21.8 & 198,280 & 19.5 & 420,040 & 41.2 & 23,480 & 2.3 \\
1987 & $1,069,690$ & 248,630 & 23.2 & 218,600 & 20.4 & 467,230 & 43.7 & 30,030 & 2.8 \\
1988 & $1,099,470$ & 248,370 & 22.6 & 227,110 & 20.7 & 475,480 & 43.2 & 21,260 & 1.9 \\
1989 & $1,125,410$ & 253,710 & 22.5 & 236,300 & 21.0 & 490,010 & 43.5 & 17,410 & 1.5 \\
1990 & $1,159,370$ & 269,500 & 23.2 & 240,580 & 20.8 & 510,080 & 44.0 & 28,920 & 2.5 \\
1991 & $1,191,930$ & 273,190 & 22.9 & 231,870 & 19.5 & 505,060 & 42.4 & 41,320 & 3.5 \\
1992 & $1,253,290$ & 293,330 & 23.4 & 231,750 & 18.5 & 525,080 & 41.9 & 61,580 & 4.9 \\
1993 & $1,334,050$ & 312,620 & 23.4 & 264,170 & 19.8 & 576,790 & 43.2 & 48,450 & 3.6 \\
1994 & $1,400,760$ & 330,810 & 23.6 & 284,730 & 20.3 & 615,540 & 43.9 & 46,080 & 3.3 \\
1995 & $1,471,800$ & 355,940 & 24.2 & n.a. & n.a. & n.a. & n.a. & n.a. & n.a. \\
Average & $1,126,964$ & 257,544 & 22.4 & 217,757 & 19.7 & 470,743 & 42.0 & 29,208 & 2.5 \\
\hline Notes & Sound &
\end{tabular}

Notes: $\quad$ Source- $10 \%$ random samples of T1 files. For income-tax filers whose self-employment earnings are the dominant source of earnings in the year. 
Table 2: Key Variable Sample Statistics and Regression Results on Self-Employment Flows

\begin{tabular}{|c|c|c|c|c|c|c|}
\hline & \multicolumn{6}{|c|}{ Sample Statistics } \\
\hline & \multicolumn{2}{|c|}{ Men \& Women } & \multicolumn{2}{|c|}{ Men } & \multicolumn{2}{|c|}{ Women } \\
\hline & Mean & Std. Dev. & Mean & Std. Dev. & Mean & Std. Dev. \\
\hline \multicolumn{7}{|l|}{ 1981-1995: } \\
\hline Ln(SE Rate) & 2.231 & 0.328 & 2.480 & 0.346 & 1.737 & 0.336 \\
\hline Ln(URate) & 2.373 & 0.331 & 2.379 & 0.349 & 2.365 & 0.317 \\
\hline Ln(FTPE Rate) & 4.294 & 0.036 & 4.386 & 0.042 & 4.156 & 0.039 \\
\hline \multicolumn{7}{|l|}{ 1982-1995: } \\
\hline Ln(Entry Rate) & 0.661 & 0.251 & 0.765 & 0.237 & 0.492 & 0.313 \\
\hline Ln(URate) & 2.395 & 0.313 & 2.406 & 0.325 & 2.380 & 0.307 \\
\hline Ln(FTPE Rate) & 4.290 & 0.033 & 4.382 & 0.039 & 3.541 & 0.116 \\
\hline \multicolumn{7}{|l|}{ 1981-1994: } \\
\hline Ln(Exit Rate) & 2.936 & 0.171 & 2.836 & 0.196 & 3.178 & 0.129 \\
\hline Ln(URate) & 2.376 & 0.333 & 2.379 & 0.351 & 2.371 & 0.319 \\
\hline \multirow[t]{4}{*}{ Ln(FTPE Rate) } & 4.294 & 0.037 & 4.079 & 0.106 & 4.156 & 0.040 \\
\hline & \multicolumn{6}{|c|}{ Fixed Effects Model Full Pooling GLS Regression Results } \\
\hline & \multicolumn{2}{|c|}{ Dep. Var. $=$ Ln(SE Rate $)$} & \multicolumn{2}{|c|}{$\frac{\text { Dep. Var. }=\text { Ln(Entry Rate })}{\text { Std. Error }}$} & \multicolumn{2}{|c|}{ Dep. Var. $=$ Ln $($ Exit Rate $)$} \\
\hline & Coefficient & Std. Error & Coefficient & Std. Error & Coefficient & Std. Error \\
\hline \multicolumn{7}{|c|}{ Indep. Var. = Ln(URate): } \\
\hline Men \& Women & -0.044 & 0.009 & -0.178 & 0.030 & -0.140 & 0.011 \\
\hline Men & -0.036 & 0.009 & -0.060 & 0.024 & -0.133 & 0.013 \\
\hline Women & -0.039 & 0.011 & -0.289 & 0.038 & -0.135 & 0.022 \\
\hline \multicolumn{7}{|c|}{ Indep. Var. = Ln(FTPE Rate): } \\
\hline Men \& Women & 0.340 & 0.070 & 1.140 & 0.201 & 0.985 & 0.090 \\
\hline Men & 0.300 & 0.078 & 0.455 & 0.189 & 1.152 & 0.113 \\
\hline Women & 0.259 & 0.060 & 1.808 & 0.112 & 0.690 & 0.132 \\
\hline
\end{tabular}

Notes: For personal income tax filers whose self-employment earnings are their main source of earnings in the year. The sample period is 1981-1995 for the self-employment rate regression; 1982-1995 for the entry rate regression; and 1981-1994 for the exit rate regression. Additional explanatory variables included in the regressions are the constant term, log of the annual provincial labour force participation rate, 9 provincial dummy variables (Ontario being the omitted case), and a dummy variable indicating time. Due to table length, results on these controls are not reported here but available upon request. Regressions for individuals with selfemployment earnings only and those with any self-employment earnings are also run and very similar qualitative results are obtained. They are not reported here either but also available upon request. 
Table 3: Self- vs Paid-Employment by Selected Characteristics, Canada, 1994

\begin{tabular}{|c|c|c|c|c|c|c|}
\hline & \multicolumn{3}{|c|}{ Self-Employment } & \multicolumn{3}{|c|}{ Paid-Employment } \\
\hline & Any & Mainly & Only & Any & Mainly & Only \\
\hline & \multicolumn{6}{|c|}{ Percent } \\
\hline As proportion of population & 11.6 & 10.5 & 9.6 & 61.8 & 60.9 & 59.8 \\
\hline \multicolumn{7}{|l|}{ Gender: } \\
\hline Male & 68.2 & 68.8 & 69.6 & 52.4 & 52.3 & 52.1 \\
\hline Female & 32.8 & 31.2 & 30.4 & 47.6 & 47.7 & 47.9 \\
\hline \multicolumn{7}{|l|}{ Age: } \\
\hline $15-19$ & 1.1 & 0.7 & 0.8 & 1.7 & 1.7 & 1.6 \\
\hline $20-24$ & 2.0 & 1.8 & 1.7 & 8.0 & 8.1 & 8.1 \\
\hline $25-34$ & 21.3 & 20.2 & 19.2 & 30.5 & 30.5 & 30.5 \\
\hline $35-44$ & 34.2 & 34.3 & 34.2 & 30.1 & 30.0 & 30.0 \\
\hline $45-54$ & 27.4 & 28.5 & 29.0 & 20.9 & 20.9 & 20.9 \\
\hline $55-64$ & 14.1 & 14.6 & 15.2 & 8.9 & 8.9 & 8.9 \\
\hline \multicolumn{7}{|l|}{ Education: } \\
\hline Elementary & 7.2 & 7.8 & 8.2 & 5.0 & 5.0 & 5.0 \\
\hline Some secondary & 13.8 & 14.2 & 14.4 & 12.6 & 12.6 & 12.7 \\
\hline High School & 15.8 & 15.8 & 15.7 & 16.7 & 16.6 & 16.7 \\
\hline Some post-secondary & 11.0 & 10.5 & 10.4 & 12.8 & 12.8 & 12.8 \\
\hline Post-secondary certificate & 34.0 & 33.7 & 33.1 & 36.3 & 36.3 & 36.3 \\
\hline University+ & 18.2 & 18.1 & 18.3 & 16.6 & 16.7 & 16.6 \\
\hline \multicolumn{7}{|l|}{ Province: } \\
\hline Nfld & 1.4 & 1.3 & 1.3 & 1.9 & 1.9 & 1.9 \\
\hline PEI & 0.5 & 0.5 & 0.5 & 0.5 & 0.5 & 0.5 \\
\hline NS & 2.2 & 1.9 & 1.8 & 3.2 & 3.2 & 3.2 \\
\hline NB & 1.9 & 1.9 & 1.7 & 2.6 & 2.6 & 2.6 \\
\hline Que & 20.2 & 21.0 & 21.5 & 24.7 & 24.8 & 25.1 \\
\hline Ont & 35.6 & 36.5 & 37.0 & 37.3 & 37.4 & 37.6 \\
\hline Man & 4.7 & 4.1 & 3.8 & 4.0 & 3.9 & 3.8 \\
\hline Sask & 4.8 & 4.3 & 4.1 & 3.3 & 3.3 & 3.1 \\
\hline Alta & 12.8 & 12.6 & 11.6 & 9.6 & 9.5 & 9.3 \\
\hline $\mathrm{BC}$ & 16.0 & 16.0 & 16.6 & 12.9 & 12.9 & 12.9 \\
\hline \multicolumn{7}{|l|}{ Industry: } \\
\hline Primary & 11.9 & 12.3 & 11.7 & 3.8 & 3.6 & 3.5 \\
\hline Manufacturing & 7.3 & 6.2 & 6.2 & 18.3 & 18.5 & 18.5 \\
\hline Construction & 13.9 & 14.5 & 15.2 & 5.2 & 5.2 & 5.1 \\
\hline $\begin{array}{l}\text { Transportation, communication } \\
\text { and utilities }\end{array}$ & 5.3 & 5.0 & 5.1 & 8.1 & 8.2 & 8.2 \\
\hline Sales & 18.0 & 18.7 & 18.6 & 15.2 & 15.2 & 15.2 \\
\hline Finance, insurance and real estate & 5.9 & 5.8 & 5.9 & 5.9 & 5.9 & 5.9 \\
\hline Business services & 10.1 & 10.4 & 10.6 & 4.9 & 4.9 & 4.8 \\
\hline Government services & 0.5 & 0.0 & 0.0 & 8.1 & 8.2 & 8.3 \\
\hline Education services & 1.9 & 1.1 & 0.8 & 9.0 & 9.1 & 9.0 \\
\hline Health and social services & 6.1 & 5.9 & 6.0 & 10.5 & 10.6 & 10.6 \\
\hline Personal services & 3.5 & 3.5 & 3.5 & 5.2 & 5.2 & 5.2 \\
\hline Other services & 15.4 & 16.4 & 16.4 & 5.4 & 5.3 & 5.2 \\
\hline Missing & 0.2 & 0.1 & 0.1 & 0.4 & 0.4 & 0.3 \\
\hline
\end{tabular}


Table 4: Self- vs Paid-Employment Earnings and Hours, Canada, 1994

\begin{tabular}{|c|c|c|c|c|c|c|}
\hline & \multicolumn{2}{|l|}{$\overline{A l l}$} & \multicolumn{2}{|l|}{$\overline{\text { Men }}$} & \multicolumn{2}{|c|}{ Women } \\
\hline & Self-Employed & Employee & Self-Employed & Employee & Self-Employed & Employee \\
\hline Average Earnings & 27,671 & 29,992 & 30,691 & 36,385 & 20,116 & 22,990 \\
\hline (Std. Dev.) & $(40,930)$ & $(21,979)$ & $(44,084)$ & $(24,848)$ & $(30,410)$ & $(15,559)$ \\
\hline Median Earnings & 17,803 & 27,027 & 20,000 & 34,075 & 10,237 & 20,997 \\
\hline Earnings Distribution: & & & Percer & & & \\
\hline Under 20,000 & 56.4 & 36.4 & 50.2 & 25.9 & 71.9 & 47.9 \\
\hline $20,001-40,000$ & 27.8 & 37.1 & 32.1 & 35.4 & 16.9 & 39.1 \\
\hline $40,001-60,000$ & 7.8 & 19.3 & 8.7 & 27.2 & 5.6 & 10.6 \\
\hline $60,001-80,000$ & 2.7 & 5.1 & 3.3 & 7.9 & 1.2 & 2.0 \\
\hline $80,001+$ & 5.4 & 2.0 & 5.7 & 3.5 & 4.6 & 0.4 \\
\hline Average Hours & 2,287 & 1,767 & 2,480 & 1,942 & 1,805 & 1,576 \\
\hline (Std. Dev.) & (941) & (668) & $(849)$ & (633) & (985) & $(653)$ \\
\hline Median Hours & 2,088 & 1,956 & 2,508 & 2,088 & 1,824 & 1,824 \\
\hline Hours Distribution: & & & Percer & & & \\
\hline Under 1,500 & 16.9 & 26.5 & 8.1 & 17.4 & 38.8 & 36.5 \\
\hline $1,501-2,000$ & 11.8 & 27.3 & 11.0 & 20.1 & 13.9 & 35.3 \\
\hline $2,001-2,500$ & 27.9 & 39.2 & 30.3 & 51.6 & 21.9 & 25.6 \\
\hline $2,501+$ & 43.4 & 7.0 & 50.6 & 10.9 & 25.4 & 2.7 \\
\hline
\end{tabular}

Notes: For those with only self-employment or paid-employment who reported positive earnings. 
Table 5: Entries into Self- vs Paid-Employment, Canada, 1994

\begin{tabular}{|c|c|c|c|c|c|}
\hline & \multicolumn{5}{|c|}{ Labour Market Status Transition } \\
\hline & One-week & One-month & Three-month & Six-month & One-year \\
\hline & \multicolumn{5}{|c|}{ Entry into any self-employment (\%) } \\
\hline From paid-employment & 37.8 & 36.7 & 39.9 & 43.4 & 48.3 \\
\hline self-employment & n.a. & 6.5 & 10.2 & 11.5 & 15.5 \\
\hline unemployment & 30.1 & 29.0 & 24.8 & 20.7 & 11.5 \\
\hline not in the labour force & 32.2 & 27.8 & 23.7 & 21.4 & 20.1 \\
\hline \multirow[t]{2}{*}{ Missing } & 0.0 & 0.0 & 1.4 & 3.1 & 4.6 \\
\hline & \multicolumn{5}{|c|}{ Entry into any paid-employment (\%) } \\
\hline From paid-employment & 31.1 & 36.6 & 40.8 & 49.6 & 49.3 \\
\hline self-employment & 3.6 & 3.2 & 3.5 & 4.1 & 4.5 \\
\hline unemployment & 57.3 & 47.1 & 35.9 & 23.6 & 16.1 \\
\hline not in the labour force & 8.1 & 12.4 & 16.3 & 14.6 & 14.9 \\
\hline \multirow[t]{2}{*}{ missing } & 0.0 & 0.7 & 3.5 & 8.1 & 15.2 \\
\hline & \multicolumn{5}{|c|}{ Entry into main self-employment (\%) } \\
\hline From paid-employment & 27.6 & 25.2 & 32.3 & 37.1 & 42.2 \\
\hline self-employment & n.a. & 7.9 & 8.9 & 9.9 & 17.1 \\
\hline unemployment & 33.2 & 33.4 & 29.7 & 25.4 & 10.5 \\
\hline not in the labour force & 39.2 & 33.5 & 27.2 & 23.9 & 25.2 \\
\hline \multirow[t]{2}{*}{ missing } & 0.0 & 0.0 & 1.9 & 3.7 & 4.9 \\
\hline & \multicolumn{5}{|c|}{ Entry into main paid-employment (\%) } \\
\hline From paid-employment & 31.2 & 37.2 & 41.1 & 50.4 & 49.3 \\
\hline self-employment & 2.6 & 1.9 & 2.3 & 2.9 & 3.7 \\
\hline unemployment & 58.6 & 47.9 & 36.6 & 23.7 & 16.5 \\
\hline not in the labour force & 7.6 & 12.2 & 16.5 & 14.8 & 15.3 \\
\hline missing & 0.0 & 0.8 & 3.4 & 8.2 & 15.2 \\
\hline
\end{tabular}


Table 6: Exits out of Self- vs Paid-Employment, Canada, 1993

\begin{tabular}{|c|c|c|c|c|c|}
\hline & \multicolumn{5}{|c|}{ Labour Market Status Transition } \\
\hline & One-week & One-month & Three-month & Six-month & One-year \\
\hline & \multicolumn{5}{|c|}{ Exits out of any self-employment (\%) } \\
\hline To paid-employment & 35.8 & 31.4 & 35.9 & 39.4 & 40.3 \\
\hline self-employment & n.a. & 9.0 & 12.0 & 12.8 & 17.7 \\
\hline unemployment & 23.7 & 21.9 & 16.3 & 14.3 & 12.2 \\
\hline not in the labour force & 40.5 & 37.8 & 35.7 & 33.2 & 26.8 \\
\hline \multirow[t]{2}{*}{ Missing } & 0.0 & 0.0 & 0.1 & 0.3 & 3.1 \\
\hline & \multicolumn{5}{|c|}{ Exits out of any paid-employment (\%) } \\
\hline To paid-employment & 29.8 & 32.4 & 39.6 & 48.7 & 56.5 \\
\hline self-employment & 3.0 & 4.9 & 5.2 & 5.7 & 6.1 \\
\hline unemployment & 37.3 & 36.0 & 32.0 & 23.7 & 15.3 \\
\hline not in the labour force & 29.9 & 26.5 & 21.8 & 19.4 & 18.4 \\
\hline \multirow[t]{2}{*}{ missing } & 0.0 & 0.2 & 1.4 & 2.5 & 3.7 \\
\hline & \multicolumn{5}{|c|}{ Exits out of main self-employment (\%) } \\
\hline To paid-employment & 25.4 & 19.3 & 23.9 & 28.7 & 31.7 \\
\hline self-employment & n.a. & 10.5 & 14.8 & 15.9 & 21.4 \\
\hline unemployment & 24.3 & 23.3 & 17.1 & 15.2 & 11.6 \\
\hline not in the labour force & 50.3 & 46.9 & 44.2 & 39.9 & 33.1 \\
\hline \multirow[t]{2}{*}{ missing } & 0.0 & 0.0 & 0.2 & 0.4 & 2.3 \\
\hline & \multicolumn{5}{|c|}{ Exits out of main paid-employment (\%) } \\
\hline To paid-employment & 28.8 & 33.8 & 41.2 & 50.3 & 58.1 \\
\hline self-employment & 2.3 & 1.8 & 2.0 & 2.6 & 3.5 \\
\hline unemployment & 38.4 & 37.1 & 33.0 & 24.5 & 15.7 \\
\hline not in the labour force & 30.5 & 27.2 & 22.3 & 20.0 & 19.0 \\
\hline missing & 0.0 & 0.2 & 1.5 & 2.6 & 3.8 \\
\hline
\end{tabular}


Table 7: Logistic Regression Results and Estimated Probability of Entering/Leaving Self-Employment

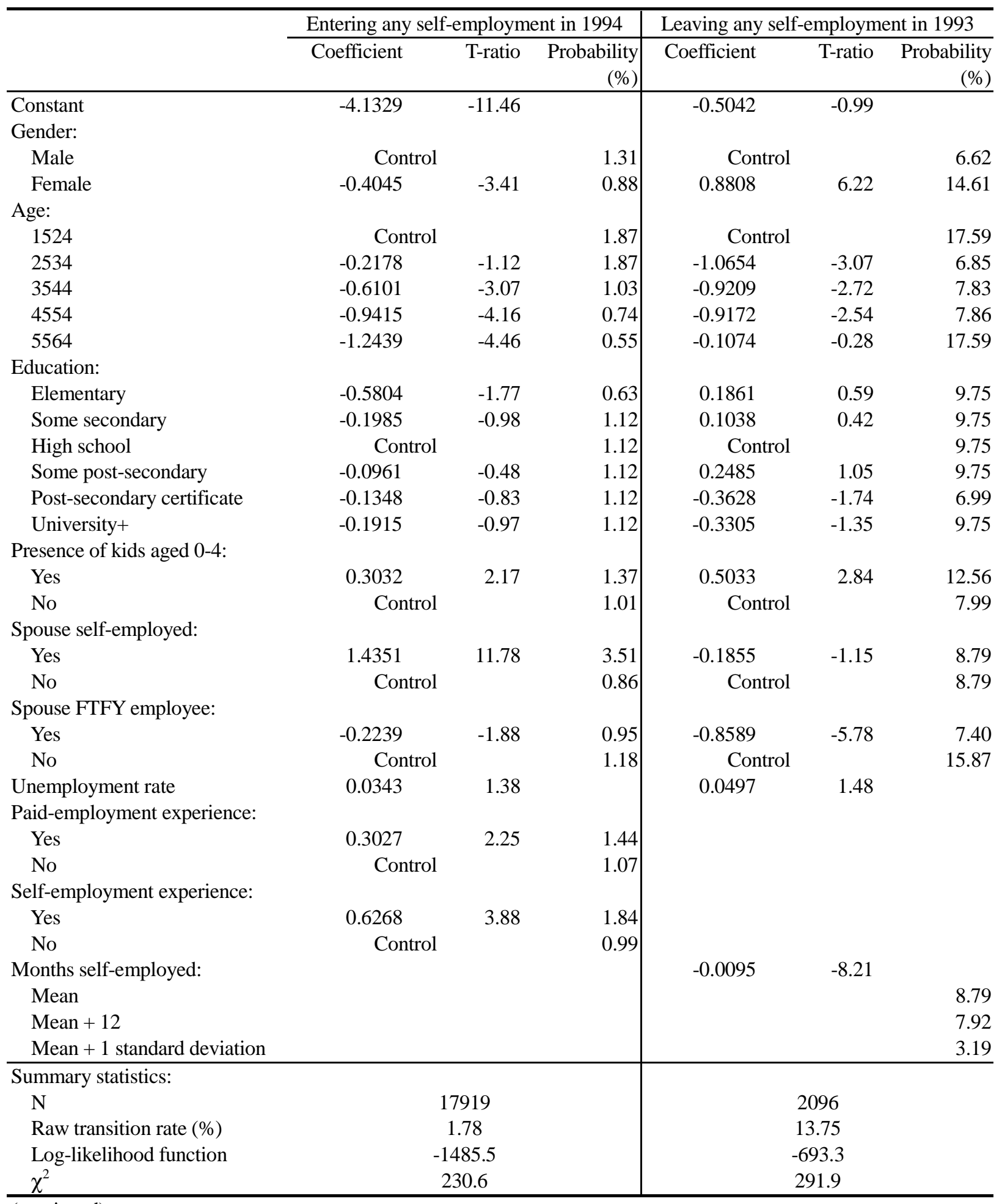

(continued) 
Table 7: (cont.)

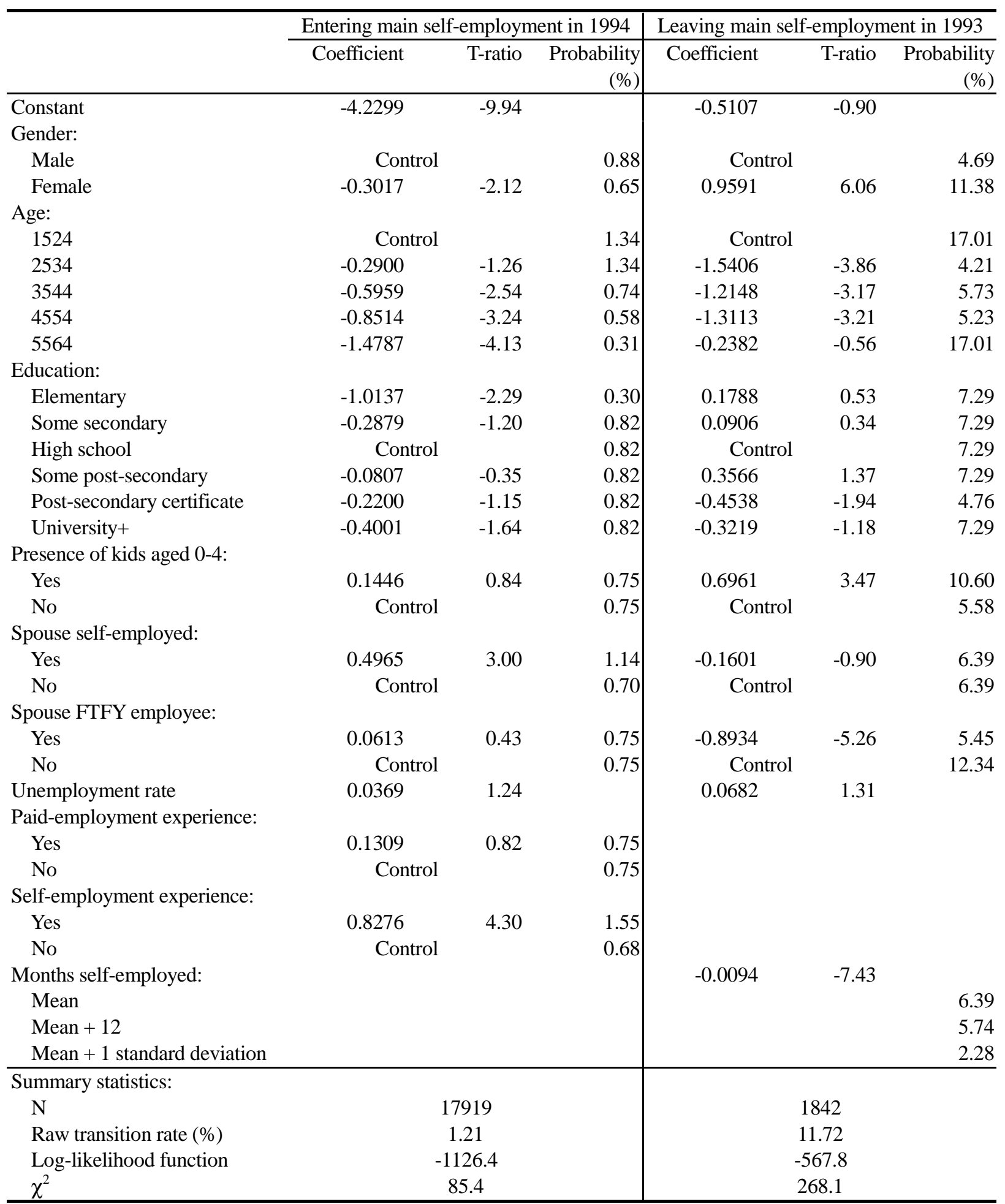

Notes: Probabilities are calculated by setting coefficients insignificantly different from zero at $10 \%$ to zero and evaluated at the mean. For dummy variables, this is done by using the sum of the unweighted coefficient of the variable and the weighted coefficients of other groups of dummy variables, where the weight being the corresponding variable's share in the sample. 


\section{Figure 1: Cyclical Fluctuations of Self-Employment Entries and Exits, Canada, 1981-1995}

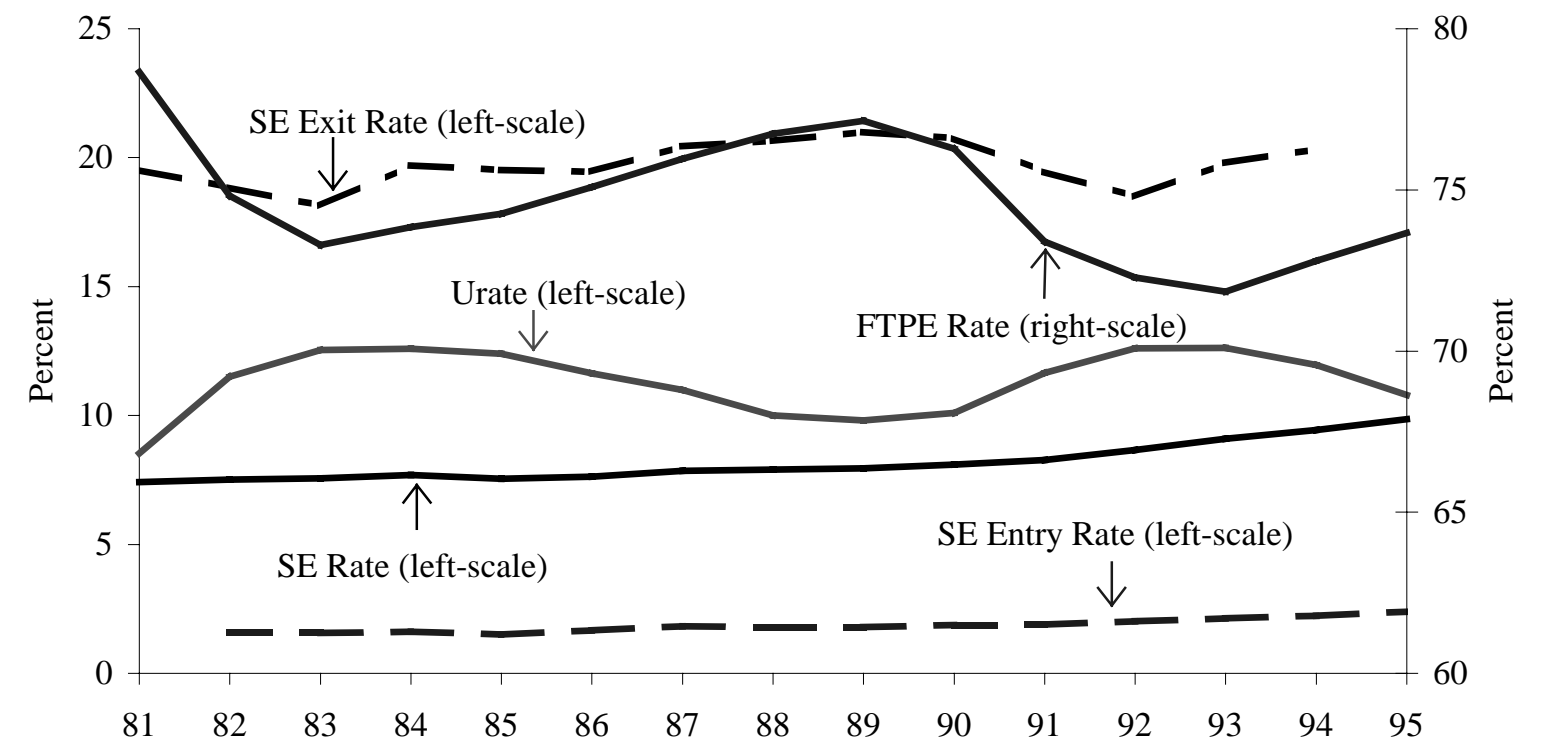

Notes: Source- Labour Force Survey and 10\% random samples of T1 files. For income-tax filers whose selfemployment earnings are the main source of earnings in the year. 


\section{Appendix: Sample Means and Standard deviations}

\begin{tabular}{|c|c|c|c|c|c|c|}
\hline & \multicolumn{2}{|c|}{ Entering SE in 1994} & \multicolumn{2}{|c|}{ Leaving any SE in 1993} & \multicolumn{2}{|c|}{ Leaving main SE in 1993} \\
\hline & Mean & Std. Dev. & Mean & Std. Dev. & Mean & Std. Dev. \\
\hline$\overline{\text { Female }}$ & 0.505 & 0.500 & 0.348 & 0.476 & 0.341 & 0.474 \\
\hline Age2534 & 0.269 & 0.444 & 0.223 & 0.416 & 0.218 & 0.413 \\
\hline Age3544 & 0.280 & 0.449 & 0.339 & 0.474 & 0.334 & 0.472 \\
\hline Age4554 & 0.213 & 0.410 & 0.267 & 0.443 & 0.273 & 0.446 \\
\hline Age5564 & 0.159 & 0.366 & 0.147 & 0.354 & 0.153 & 0.360 \\
\hline Elementary & 0.091 & 0.287 & 0.080 & 0.271 & 0.084 & 0.277 \\
\hline Some secondary & 0.145 & 0.353 & 0.142 & 0.350 & 0.148 & 0.355 \\
\hline Some post-secondary & 0.123 & 0.329 & 0.119 & 0.324 & 0.117 & 0.322 \\
\hline Post-secondary certificate & 0.331 & 0.471 & 0.317 & 0.466 & 0.313 & 0.464 \\
\hline University+ & 0.146 & 0.353 & 0.177 & 0.381 & 0.171 & 0.377 \\
\hline Presence of kids aged 0-4 & 0.176 & 0.381 & 0.207 & 0.405 & 0.207 & 0.405 \\
\hline Spouse self-employed & 0.154 & 0.361 & 0.283 & 0.451 & 0.279 & 0.448 \\
\hline Spouse FTFY employee & 0.471 & 0.499 & 0.783 & 0.413 & 0.810 & 0.392 \\
\hline Unemployment rate & 10.522 & 2.158 & 10.969 & 1.997 & 10.987 & 1.971 \\
\hline Paid-employment experience & 0.613 & 0.487 & & & & \\
\hline Self-employment experience & 0.120 & 0.325 & & & & \\
\hline Months self-employed & & & 122.883 & 112.929 & 125.997 & 113.834 \\
\hline$\overline{\mathrm{N}}$ & 179 & & 20 & & 18 & \\
\hline
\end{tabular}




\section{References}

Abell, P., H. Khalaf and D. Smeaton (1995), “An Exploration of Entry to and Exit from SelfEmployment", Discussion Paper No. 224, London School of Economics Centre for Economic Performance.

Acs, Z. J. , D. B. Audretsch and D. S. Evans (1994), "Why Does the Self-Employment Rate Vary Across Countries and Over Time?", Discussion Paper No. 871, Centre for Economic Policy Research.

Aronson, R. (1991), Self-Employment: A Labor Market Perspective, Ithaca, New York: ILR Press.

Bernhardt, I. (1994), "Comparative advantage in self-employment and paid work", Canadian Journal of Economics, 27 (2), 273-89.

Blanchflower, D. G. and A. J. Oswald. (1998), “What Makes an Entrepreneur?”, Journal of Labor Economics, 16 (1), 26-60.

Blau, D. M. (1987), “A Time-Series Analysis of Self-Employment in the United States”, Journal of Political Economy, 95 (3), 445-67.

Borjas, G. J. (1986), "The Self-Employment Experience of Immigrants", The Journal of Human Resources, 21 (4), 485-506.

Carrasco, R. (1997), “Transitions to and from Self-Employment in Spain: An Empirical Analysis”, CENTROS DE ESTUDIOS MONETARIOS Y FINANCIEROS (CEMFI) Working Paper No. 9710.

Casson, M. (1991), The Entrepreneur: An Economic Theory, Worcester: Billing and Sons Ltd.

Evans, D. S. and B. Jovanovic (1989), "An Estimated Model of Entrepreneurial Choice under Liquidity Constraints", Journal of Political Economy, 97 (4), 808-27.

Evans, D. S. and L. S. Leighton (1989a), "The Determinants of Changes in U.S. Self-Employment", Small Business Economics, 1 (2), 111-20.

Evans, D. S. and L. S. Leighton (1989b), "Some Empirical Aspects of Entrepreneurship", The American Economic Review, 79 (3), 519-35.

Fairlie, R. (1997), "The Absence of the African-American Owned Business: An Analysis of the Dynamics of Self-Employment", mimeo, Department of Economics, University of California, Santa Cruz.

Gauthier, J. and R. Roy (1997), "Diverging Trends in Self-Employment in Canada”, Working Paper R-97-13E, Applied Research Branch, Human Resources Development Canada. 
Highfield, R. and R. Smiley (1987), "New Business Starts and Economic Activity”, International Journal of Industrial Organization, 5, 51-66.

Holmes, T. J. and J. A. Schmitz (1990), “A Theory of Entrepreneurship and Its Application to the Study of Business Transfers”, Journal of Political Economy, 89, 265-94.

Kihlstrom, R. E. and J. J. Laffont (1979), "A General Equilibrium Entrepreneurial Theory of Firm Formation Based on Risk Aversion”, Journal of Political Economy, 87, 719-48.

Kmenta, J. (1971), Elements of Econometrics, New York: Macmillan.

Lin, Z., J. Yates and G. Picot (1998), "Rising self-employment in the midst of high unemployment: An empirical analysis of recent developments in Canada", 1998 Canadian Economics Association meetings; Statistics Canada Analytical Studies Branch Research Paper (forthcoming).

Parker, S. C. (1996), “A Time Series Model of Self-Employment under Uncertainty”, Economica, $63,459-75$.

Picot, G., M. Manser and Z. Lin (1998), "The Role of Self-Employment in Job Creation in Canada and the United States", OECD-CERF-CILN international conference on self-employment, Burlington, Ontario, Canada.

Picot, G. and Z. Lin (1997), "Are Canadians More Likely to Lose Their Jobs in the 1990s?", Canadian Economic Observer, September 1997, 3.1-3.18.

Rees, H. and A. Shah (1986), "An Empirical Analysis of Self-Employment in the U.K.", Journal of Applied Econometrics, 1, 95-108.

Rosen, S. (1983), "Economics and Entrepreneurs", in J. Ronen (ed.), Entrepreneurship, Lexington, MA: Lexington Books.

Statistics Canada (1997), Labour Force Update: The Self-Employed, Catalogue 71-005-XPB.

Storey, D. J. (1991), "The Birth of New Firms - Does Unemployment Matter?: A Review of the Evidence”, Small Business Economics, 3 (3), 167-78.

Taylor, M. P. (1996), "Earnings, Independence or Unemployment: Why Become Self-Employed?", Oxford Bulletin of Economics and Statistics, 58 (2), 253-66.

Van Praag, C. M. and H. Van Ophem (1995), "Determinants of Willingness and Opportunity to Start as an Entrepreneur”, Kyklos, 48 (4), 513-40. 